\title{
OPTIMASI PROSES MESIN STRETCH BLOW MOULDING PADA BOTOL 600 ML DENGAN METODE RSM (RESPONSE SURFACE METHODOLOGY) STUDI KASUS DI PT. UNIPLASTINDO INTERBUANA
}

\author{
Mochamad Mas'ud \\ Fakultas Teknik, Program Studi Teknik Mesin \\ Universitas Yudharta Pasuruan \\ Email:masud.teknik@yudharta.ac.id
}

\begin{abstract}
ABSTRAK
Pada proses produksi Aqua botol plastik $600 \mathrm{ml}$ menggunakan mesin stretch blow moulding dengan sistem pneumatik, Pembuatan produk dengan menggunakan mesin ini memiliki faktor-faktor yang dapat mempengaruhi kualitas botol yang dihasilkan . Penyimpangan ukuran (pemerataan tebal botol dan kemiringan botol) tidak sesuai dengan spesifikasi mengakibatkan botol dibagian pundak putih dan bergelang (shrinkage). Tujuan dari penelitian ini yaitu mengoptimalkan setting parameter mesin stretch blow moulding agar menghasilkan kualitas baik pada produk botol plastik $600 \mathrm{ml}$. Adapun variable(prediktor) yang di pilih yaitu preblow (bar), preform temperature (), dan P1 point ( $\mathrm{mm}$ ), sedangkan respon yang dicari yaitu kemiringan minimal dan tebal maksimal. Metode yang di gunakan dalam penelitian ini yaitu menggunakan Response Surface Metodhology (RSM) yang mana dalam perhitungannya menggunakan software minitab 16. Dengan menggunakan Box Behnken Design dan 3 level factorial di hasilkan run 15 percobaan. Berdasarkan hasil kondisi yang optimal parameter yaitu preblow sebesar 6,5 bar, preform temperature sebesar 114, dan P1 Point sebesar $25 \mathrm{~mm}$. Dengan setting sebesar tersebut akan menghasilkan respon tebal botol sebesar 0,1446 dan kemiringan botol sebesar 0,1875.
\end{abstract}

Kata kunci : Stretch blow moulding, setting parameter dan optimasi proses

\begin{abstract}
In the $600 \mathrm{ml}$ plastic bottles Aqua production process using machine stretch blow molding with the pneumatic system, creation of products using these machines have factors that can affect the quality of the bottles produced. Deviations size (thickness equalization bottle and tilt the bottle) does not comply with the specifications resulting bottle of white and a flanged shoulder section (shrinkage). The purpose of this study is to optimize the parameter settings stretch blow molding machine to produce a good quality product plastic bottle of $600 \mathrm{ml}$. The variables (predictors) were selected namely preblow (bar), preform temperature $\left({ }^{\circ} \mathrm{C}\right)$, and $\mathrm{P} 1$ point $(\mathrm{mm})$, while the response is sought, namely the slope minimum and maximum thickness. The method used in this research is using Response Surface Metodhology (RSM) which in its calculations using Minitab software 16. By using the Box Behnken Design and 3-level factorial experiment produced 15 runs. Based on the results of the parameters are optimal conditions preblow of 6.5 bar, preform temperature of
\end{abstract}


$114{ }^{\circ} \mathrm{C}$, and P1 Point by $25 \mathrm{~mm}$. By setting will produce a response of thick bottle and tilt the bottle at 0.1446 at 0.1875 .

Keywords : Stretch blow molding, setting parameter, optimazation process

\section{PENDAHULUAN}

Terjualnya suatu produk dipasaran dapat dipengaruhi oleh beberapa hal salah satunya yaitu ditentukan dari kemasannya. Kemasan yang buruk dapat menyebabkan gangguan terhadap keberadaan atau kualitas suatu produk. Sebaliknya jika kemasan baik maka akan lebih menjamin kualitas produk tersebut. Kemasan suatu produk menjadi sangat berperan penting karena fungsi dari kemasan tersebut adalah melindungi isi produk supaya aman sehingga dapat dijual di pasaran.

Kemasan dari bahan plastik dapat dibuat atau dicetak menjadi bentuk yang bermacammacam, salah satunya adalah dalam bentuk botol. Botol plastik juga dapat diberi label atau diberi pewarnaan yang bagus sehingga dapat memperkuat ketertarikan konsumen terhadap produk. Salah satu proses pembuatan botol plastik di PT.Uniplastindo Interbuana yaitu dengan cara peniupan menggunakan kekuatan udara, proses ini disebut dengan proses stretch blow molding. Pembuatan produk dengan menggunakan mesin ini memiliki faktor-faktor yang dapat mempengaruhi kualitas botol yang dihasilkan yaitu: temperatur preform $\left({ }^{\circ} \mathrm{C}\right)$, preblowing (bar), $\mathrm{p} 1$ point $(\mathrm{mm})$. Pengaturan faktor-faktor tersebut selama ini belum memberikan hasil yang memuaskan (banyak penyimpangan ukuran dari target yang ditentukan) sehingga perlu ditetapkan pengaturan (setting) mesin supaya optimum. Variabel kualitas botol plastik dapat diukur dengan variabel-variabel antara lain : pemerataan tebal botol dan kemiringan botol.

Penelitian yang dilakukan adalah mengamati produk aqua $600 \mathrm{ml}$. Alasan pemilihan produk ini adalah masih terdapat produk yang keluar dari spesifikasi kualitas yang diharapkan oleh perusahaan. Oleh karena itu perlu dilakukan penelitian lebih lanjut untuk mendapatkan ukuran kualitas yang tepat dan proses yang kapabel.

\section{LANDASAN TEORI}

\section{Plastik dan Mesin Stretch Blow Moulding}

Plastik adalah suatu polimer yang mempunyai sifat-sifat unik dan luar biasa. Polimer adalah suatu bahan yang terdiri dari unit molekul yang disebut monomer. Jika monomernya sejenis disebut homopolimer, dan jika monomernya berbeda akan menghasilkan kopolimer.

Polimer alam yang telah kita kenal antara lain : selulosa, protein, karet alam dan sejenisnya. Pada mulanya manusia menggunakan polimer alam hanya untuk membuat perkakas dan senjata, tetapi keadaan ini hanya bertahan hingga akhir abad 19 dan selanjutnya manusia mulai memodifikasi polimer menjadi plastik. Plastik yang pertama kali dibuat secara komersial adalah nitroselulosa. Material plastik telah berkembang pesat dan sekarang mempunyai peranan yang sangat penting di bidang elektronika pertanian, tekstil, transportasi, furniture, konstruksi, kemasan kosmetik, mainan anak - anak dan produk - produk industri lainnya.

Ada beberapa teknik pembentukan polimer. Banyak kesamaan antara proses pembentukan logam dengan proses pembentukan polimer. Penentuan teknik pembentukan polimer bergantung pada beberapa faktor, diantaranya:

1. Apakah polimernya termoplastik atau thermoset

2. Jika termoplastik, pada suhu berapakah material ini melunak 
3. Kestabilan material ketika dibentuk, serta

4. Bentuk dan ukuran produk akhir

Stretch blow molding machine merupakan mesin utama dari proses blowing. Yaitu peniupan preform menjadi botol sesuai dengan cetakan yang dibuat. Mesin ini pada dasarnya terdiri dari dua bagian, yaitu bottle blowing unit dan prefrom heating unit. Infrared prefrom heating (oven), merupakan bagian dari stretch blow moulding machine dimana pada bagian ini terjadi proses pemanasan preform sebagai bentuk awal dari botol. Preform sendiri diperoleh dari unit injection machine (husky), sehingga sebelum proses blowing, preform tersebut harus dipanaskan terlebih dahulu pada bagian mesin ini.

Sedangkan pada bagian bottle blowing unit merupakan kelanjutan dari proses preform heating unit (oven) yaitu proses blowing. Setelah pemanasan dan masih dalam temperature tinggi (sehingga PET menjadi lunak) kemudian preform tersebut dimasukan oleh mesin kedalam cetakan (mould), dan kemudian dilakukan proses peniupan menjadi botol. Mesin kosme KSB4L merupakan mesin stretch blow moulding yang prosesnya sebagian besar menggunakan sistem pneumatic dan proses transfernya menggunakan berbagai sensor baik sensor temperatur, proximity, maupun sensor optic. Dan semua gerakan maupun setting parameter-nya diatur melalui sebuah monitor.

\section{Metode Respon Surface}

Metode ini menggabungkan teknik matematika dengan teknik statistika yang digunakan untuk membuat dan menganalisa suatu respon Y yang dipengaruhi oleh beberapa variabel bebas atau faktor $\mathrm{X}$ guna mengoptimalkan respon tersebut. Hubungan antara respon $\mathrm{Y}$ dan variabel bebas dapat dirumuskan sebagai berikut:

$Y=f\left(X_{1}, X_{2}, X_{3}, \ldots, X_{n}\right)+\stackrel{\circ}{a}$

dimana:

$Y=$ variabel respon

$X=$ variabel bebas/faktor $(i=1,2,3, \ldots, k)$

$\stackrel{\circ}{a}=$ error

Hubungan antara $Y$ dan $X i$ dapat dicari menggunakan orde pertama dan orde kedua, dimana model orde pertama digunakan untuk mencari daerah optimal dan model orde kedua digunakan untuk mencari titik optimal.

Adapun tahap- tahap memulai response survace methodology (RSM) antara lain :

1. Menentukan model orde pertama, dimana suatu desain eksperimen di lakukan untuk pengumpulan data dan arah penelitian. Setelah arah penelitian selanjutnya telah di peroleh kemudian di tentukan level factor untuk pengumpulan data selanjutnya.

2. Menentukan model persamaan orde kedua, penentuan model dilakukan dengan melakukan desain eksperimen dengan level yang telah di tetapkan.

3. Menentukan titik optimum dari factor-faktor yang di teliti.

Salah satu pertimbangan penting yang muncul dalam response surface methodology adalah bagaimana menentukan faktor dan level yang dapat cocok dengan model yang akan dikembangkan. Jika faktor dan level yang dipilih dalam suatu eksperimen tidak tepat maka kemungkinan terjadinya ketidakcocokan model akan sangat besar dan jika itu terjadi maka penelitian yang dilakukan bersifat bias [1,2]. 
ISSN: 1411-4348

\section{METODE PENELITIAN}

Diagram Alir Penelitian

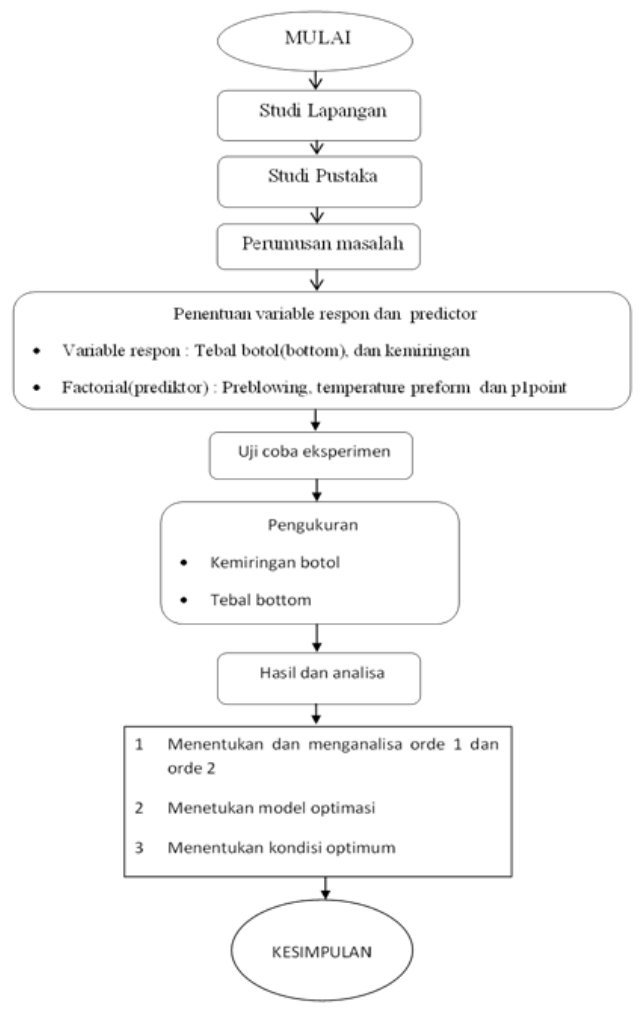

Gambar 1. Diagram alir penelitian

\section{Variabel Penelitian}

Pada penelitian ini penentuan parameter yang di gunakan yaitu sebagai berikut :

Tabel 1. Data faktor-faktor pada tiap level

\begin{tabular}{lccc}
\hline \multirow{2}{*}{ Factor } & Level low & $\begin{array}{c}\text { Level } \\
\text { medium }\end{array}$ & $\begin{array}{c}\text { Level } \\
\text { high }\end{array}$ \\
\cline { 2 - 4 } & $\mathbf{- 1}$ & $\mathbf{0}$ & $\mathbf{1}$ \\
\hline Preblow & $6,5 \mathrm{bar}$ & $7,5 \mathrm{bar}$ & $8,5 \mathrm{bar}$ \\
Pref temp & 114 & 117 & 120 \\
P1 point & $15 \mathrm{~mm}$ & $20 \mathrm{~mm}$ & $25 \mathrm{~mm}$ \\
\hline
\end{tabular}

Dengan menggunakan metode box behnken desain 3 level tersebut akan menghasilkan 15 kali percobaan.

Predictor yang digunakan dalam penelitian ini adalah preblow, preform temperature dan Pl point. Sedangkan untuk respon yang di cari yaitu tebal dan kemiringan botol. Kemiringan botol diukur dengan menggunakan alat pengukur tinggi (height gauge) digital. Adapun metode pengukurannya yaitu dengan menarik garis di empat sudut mulut botol dan mengukur tinggi sudut sudut yang telah di tetapkan tersebut. Setelah diukur selanjutnya di ambil selisih nominal terbawah/ terendah dengan nominal tertinggi. Adapun toleransi kemiringan botol yang di tetapkan oleh perusahaan yaitu $0,3 \mathrm{~mm}$.

Data yang didapatkan diolah dengan menggunakan minitab dan dianalisa berdasarkan analisa statistik $[3,4]$. 


\section{HASIL DAN ANALISA}

Berikut data hasil eksperimen yang telah dilakukan sesuai dengan metode yang digunakan.

Tabel 2. Data hasil eksperimen

\begin{tabular}{cccccc}
\hline No & $\begin{array}{c}\text { Pre } \\
\text { Blow }\end{array}$ & $\begin{array}{c}\text { Pref } \\
\text { Temp }\end{array}$ & $\begin{array}{c}\text { P1 } \\
\text { Point }\end{array}$ & $\begin{array}{c}\text { Tebal } \\
\text { Botol }\end{array}$ & $\begin{array}{c}\text { Kemiringan } \\
\text { Botol }\end{array}$ \\
\hline 1 & 6,5 & 114 & 20 & 0,14 & 0,23 \\
2 & 8,5 & 114 & 20 & 0,11 & 0,14 \\
3 & 6,5 & 120 & 20 & 0,14 & 0,15 \\
4 & 8,5 & 120 & 20 & 0,12 & 0,08 \\
5 & 6,5 & 117 & 15 & 0,12 & 0,21 \\
6 & 8,5 & 117 & 15 & 0,12 & 0,15 \\
7 & 6,5 & 117 & 25 & 0,12 & 0,22 \\
8 & 8,5 & 117 & 25 & 0,13 & 0,23 \\
9 & 7,5 & 114 & 15 & 0,14 & 0,19 \\
10 & 7,5 & 120 & 15 & 0,13 & 0,23 \\
11 & 7,5 & 114 & 25 & 0,15 & 0,21 \\
12 & 7,5 & 120 & 25 & 0,13 & 0,26 \\
13 & 7,5 & 117 & 20 & 0,12 & 0,27 \\
14 & 7,5 & 117 & 20 & 0,13 & 0,29 \\
15 & 7,5 & 117 & 20 & 0,12 & 0,25 \\
\hline
\end{tabular}

\section{Interpretasi Output Respons untuk Tebal botol}

Hasil taksiran parameter model, table ANOVA yang digunakan untuk menguji kecocokan modal dengan data dan unusual observation. Langkah awal adalah mendeteksi signifikansi model [4].
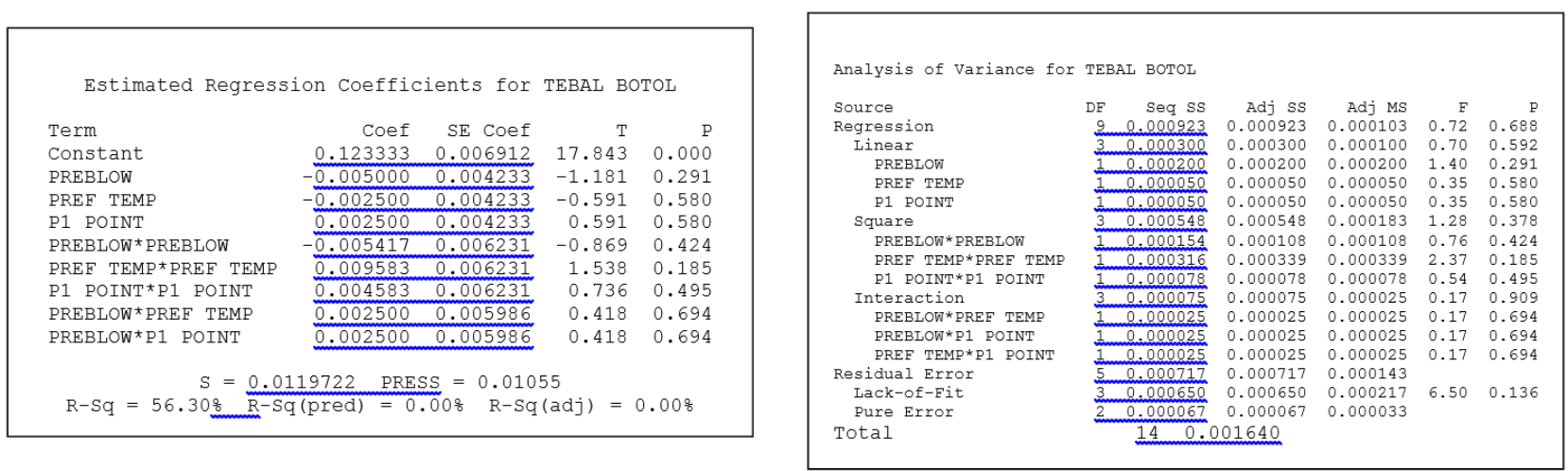

\section{Gambar 2. Analisa desain response surface tebal botol}

Untuk memeriksa kesesuaian model, tabel di atas menunjukkan bahwa $P$-value $=$ 0,136 yang berarti lebih lebih besar dari 0,05. Dengan demikian dapat disimpulkan bahwa tidak ada alasan untuk menolak $\mathrm{H}_{\mathrm{o}}$ yang artinya model tidak mengandung lack of fit atau model yang di peroleh telah sesuai dengan data [4]. 


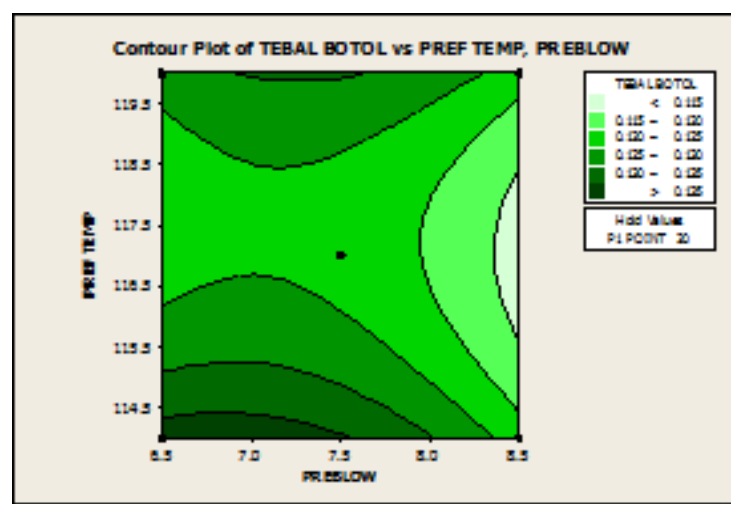

Gambar 3. Countor plot dari tebal botol

Pada contour plot di atas menjelaskan bahwa respon semakin baik apabila berada antara level 6,5- 7,5 dan 114-114,5 untuk parameter preblow dan preform temperature. Dengan menyetting preblow dan preform temperature pada level tersebut kita akan memperoleh tebal botol lebih dari 0,135 .

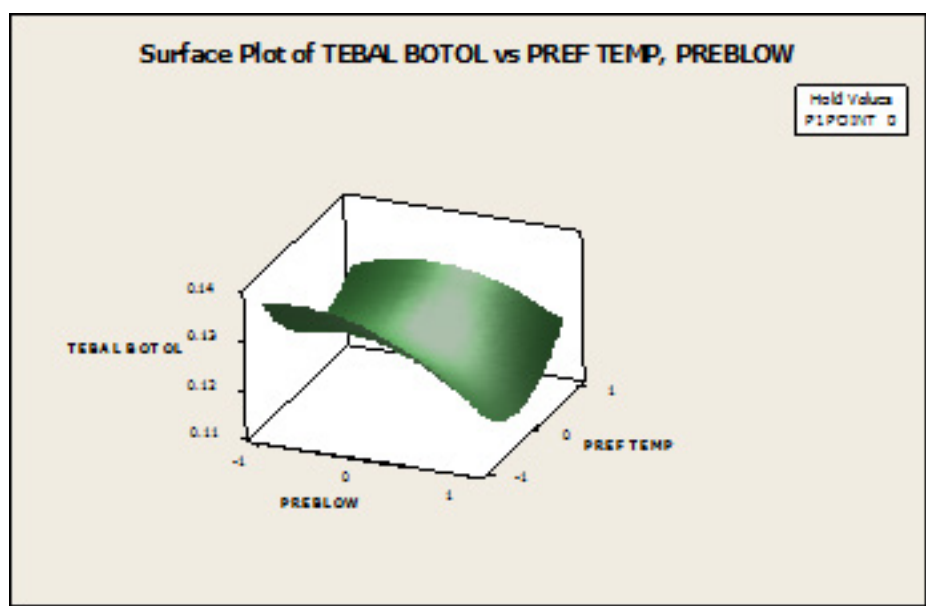

Gambar 4. Surface plot dari tebal botol

\section{Interpretasi Output Respons untuk kemiringan botol}



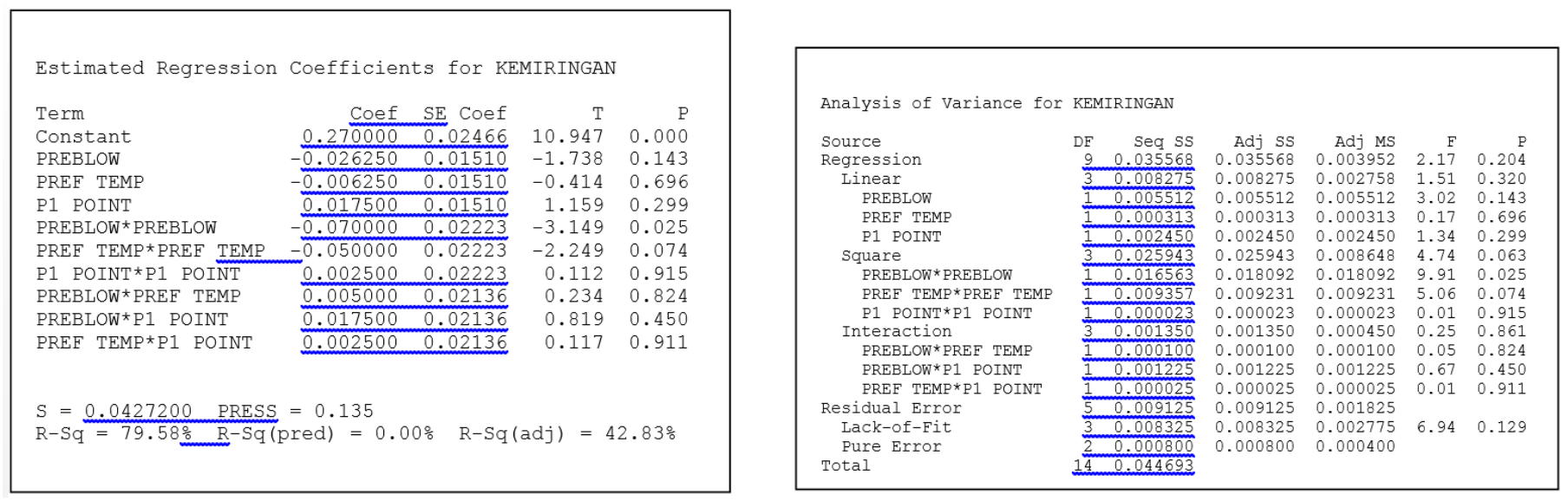

Gambar 5. Analisa desain response surface kemiringan botol

Untuk memeriksa kesesuaian model, tabel di atas menunjukkan bahwa $P$-value $=0,129$ yang berarti lebih lebih besar dari 0,05. Dengan demikian dapat di simpulkan bahwa tidak ada alasan untuk menolak $\mathrm{H}_{\mathrm{o}}$ yang artinya model tidak mengandung lack of fit atau model yang di peroleh telah sesuai [4].

Dari penduga tebal botol dan kemiringan botol di atas selanjutnya dilakukan uji normalitas, identik dan independen dan ketika di lakukan pengujian dapat disimpulkan bahwa data data yang ada sudah sesuai dan memenuhi setiap pengujian.

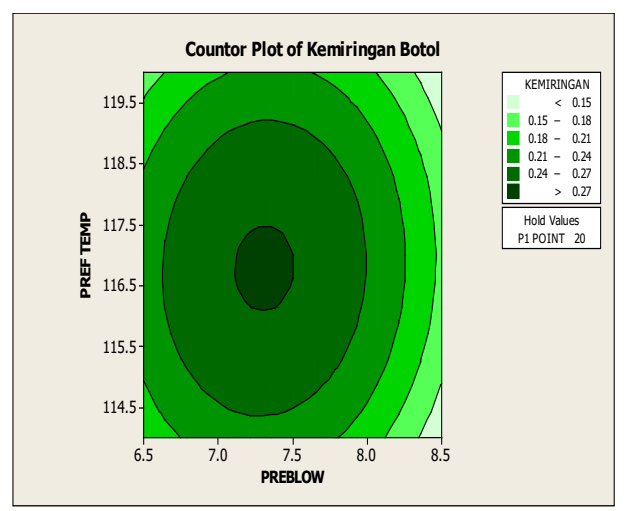

Gambar 6. Countor plot dari kemiringan botol

Pada contour plot di atas menjelaskan bahwa respon semakin baik apabila setting parameter berada antara level 8,35- 8,5 dan 114-114,2 untuk parameter preblow dan preform temperature. Dengan menyetting preblow dan preform temperature pada level tersebut kita akan memperoleh kemiringan botol kurang dari $0,15 \mathrm{~mm}$. 


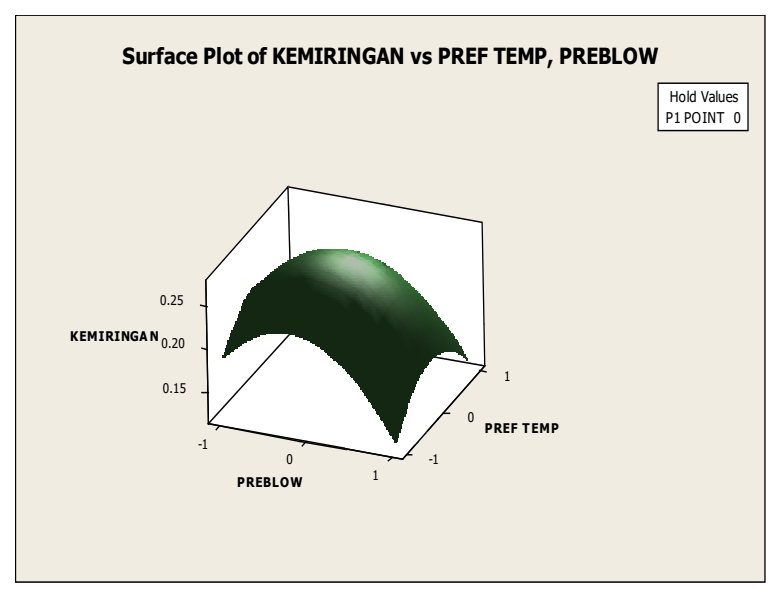

Gambar 7. Surface plot dari kemiringan botol

\section{Optimasi Parameter}

Untuk mencari respon optimum selanjutnya digunakan pendekatan desirability [4,5], dengan memberikan batasan- batasan agar respon yang diperoleh tetap sesuai dengan standar yang telah ditentukan perusahaan. Kriteria optimum yang digunakan untuk mendapatkan hasil optimal didapatkan dari perusahaan yang merupakan standar yang telah disepakati yaitu tebal botol maksimal $0.2 \mathrm{~mm}$ dan kemiringan seminimal mungkin dengan standar maksimal $0.30 \mathrm{~mm}$. Untuk mendapatkan nilai optimasi perlu digunakannya batas atas dan batas bawah dari data hasil eksperimen sebagai berikut [6]:

- Tebal botol maksimal $(0.11<\mathrm{Y}<0.20)$

- $\quad$ Kemiringan botol minimal $(<0.30)$

Berikut adalah hasil pengolahan data dengan menggunakan fitur response surface optimizer.

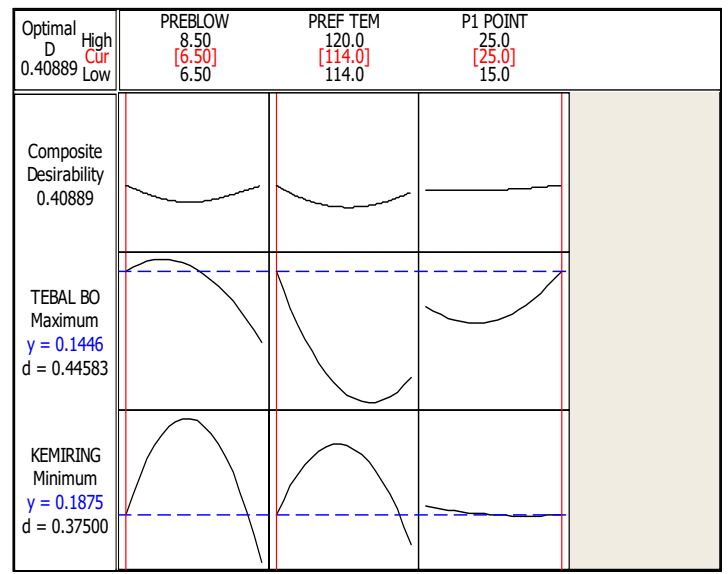

Gambar 9. Kombinasi variable proses yang menghasilkan respon optimal

Gambar di atas menampilkan bahwa global solution untuk setting parameter pada preblow sebesar 6,5 bar, preform temperature sebesar $114^{\circ} \mathrm{C}$, dan P1 Point sebesar $25 \mathrm{~mm}$. Dengan melakukan setting parameter pada level tersebut, maka akan menghasilkan variabel respon tebal botol 0,1446 $\mathrm{mm}$ dengan nilai desirability 0,44583 , kemiringan botol 0,1875 dengan nilai desirability 0,375 . 


\section{KESIMPULAN DAN SARAN}

\section{Kesimpulan}

1. Dari hasil optimasi menggunakan metode response surface di peroleh respon tebal botol sebesar 0,1446 dan kemiringan botol sebesar 0,1875 dengan nilai desirability sebesar 0,40889 .

2. Untuk tebal botol, secara individu parameter yang paling berpengaruh adalah preblowing pressure.

3. Untuk kemiringan botol, secara individu parameter yang paling berpengaruh adalah preblowing pressure.

\section{Saran}

1. Untuk setiap pengujian atau penelitian yang menggunakan Response Surface Methodology, kombinasi setting parameter yang digunakan harus di perhatikan karena kombinasi setting parameter berpengaruh terhadap output nilai signifikansi.

2. Untuk penelitian selanjutnya hendaknya menggunakan resin material plastic yang berbeda, sehingga dapat diketahui perbedaan hasil yang akhirnya dapat disimpulkan jenis resin plastic PET yang paling baik untuk produk botol $600 \mathrm{ml}$.

3. Untuk penelitian selanjutnya hendaknya juga mencoba menganalisa pengoptimalan parameter mesin pencetak preform. Dengan mengoptimalkan parameter mesin injeksi preform maka penelitian pada mesin ini selanjutnya akan lebih optimal lagi.

4. Hasil penelitian yang dilakukan merupakan solusi dalam mengatasi permasalahan sebatas perhitungan secara statistik dalam memperoleh hasil respon yang optimal. Hasil penelitian ini tidak diterapkan secara praktis akan tetapi dapat dijadikan bahan pertimbangan dalam menentukan setting parameter dalam produk yang lain.

\section{DAFTAR PUSTAKA}

[1] Misbahuddin, Hasan, dan Iqbal, 2013, Analisis data penelitian dengan Statistik. Bumi Aksara, Jakarta.

[2] Sugiono, 2012, Statistika Untuk Penelitian. Alfabeta, Bandung.

[3] Iriawan,N., dan Puji Astuti,S., 2006, Mengolah Data Statistik dengan Mudah Menggunakan Minitab 14, Andi, Yogyakarta.

[4] Suparno.,dan Antonius, 2013, Perancangan percobaan aplikasi minitab, SAS, dan Costat dalam analisis data, Alfabeta, Bandung.

[5] Hermawan,Y.,dan Astika,I.,M, 2009, Optimasi Waktu Siklus Pembuatan Kemasan Produk Chamomile 120 Ml Pada Proses Blow Molding, Cakra M 3.1,18-25.

[6] Musthofa, A, 2014, Penentuan Setting Parameter Pembuatan Botol DK 8251 B pada Proses Blow Moulding dengan Menggunakan RSM (Response Surface Methodology): Studi Kasus di PT. Rexam Packaging Indonesia, JTM OTOPRO 2.3, 47-55. 